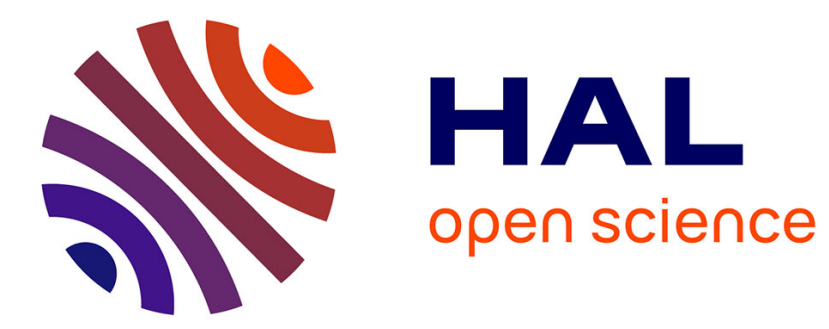

\title{
Politicizing fear of crime and insecurity in Caracas
}

\author{
Julien Rebotier
}

\section{To cite this version:}

Julien Rebotier. Politicizing fear of crime and insecurity in Caracas. Emotion, Space and Society, 2011, 4 (2), pp.104-112. 10.1016/j.emospa.2010.12.003 . halshs-00568211

\section{HAL Id: halshs-00568211 https://shs.hal.science/halshs-00568211}

Submitted on 22 Feb 2011

HAL is a multi-disciplinary open access archive for the deposit and dissemination of scientific research documents, whether they are published or not. The documents may come from teaching and research institutions in France or abroad, or from public or private research centers.
L'archive ouverte pluridisciplinaire HAL, est destinée au dépôt et à la diffusion de documents scientifiques de niveau recherche, publiés ou non, émanant des établissements d'enseignement et de recherche français ou étrangers, des laboratoires publics ou privés. 


\section{Politicizing fear of crime and insecurity in Caracas}

\section{Introduction: from insecurity to fear, the manufacturing of a meta-narrative}

Caracas. City of insecurity and chaos. Almost every week, the media is used to echo public opinion surveys that make insecurity the top concern of the Venezuelan people. Through crimes, antisocial behavior or burglary, insecurity is everywhere. According to homicide rates, Caracas is among the most violent cities in the world. The Consejo Ciudadano para la Seguridad Pública, a Mexican $\mathrm{NGO}^{1}$, has classified Caracas as the second most violent city in the world in 2009. This year, the number of homicides per 100000 inhabitants per year was about 130 (Briceño León et al. 2009) while in Bogotá it was close to 20. Such data graphically illustrate the rise of urban insecurity during the last decades of the $20^{\text {th }}$ century, on a global scale as well as in Latin-America. Fear of crime, delinquency or any kind of non-state violence has become pervasive in most cities (Davis 1998; Glassner 1999; Virilio 2007), Caracas being a critical and original example in the region (Kruijt and Koonings 1999). First, its originality comes from the fact that it is governed by a democratic regime since the late 1950s. Today's fear does neither stand in society nor in political life as a legacy of past dictatorship. Second, Venezuelan society is pacific. There are no movements such as Shining Path or Zapatista rebellion which imply massive violence and make fear a pervasive emotion over society. From the late 1950s on, a context of exceptional prosperity and democracy has contributed to shrugging off fear and violence in the social and political landscape (which does not mean they were inexistent). But what is described as the myth of an “exceptional democracy" (Ellner and Tinker Salas 2007) breaks up during the regional crisis of the 1980s, triggering off huge social and political disruptions in the rather quiet Latin American country. The insecurity that pervades today Caracas' everyday life must be rooted in a combination of long-term structural difficulties (exclusion, inequality, colonial features, which contrast with a "myth" of exceptional democracy) as well as in the important disruptions associated with the neoliberal turn from the 1970s on. In addition, the recent political changes related to the presidency of Hugo Chavez Frías have lead to critical political and social tensions. In this sense, beyond the military roots and civil war drivers of violence and fear, we find significant interest in Kessler's work (2009) on a growing feeling of insecurity in Latin America, and Caldeira's masterpiece on São Paolo (2000). Both contributions pay special attention to the role of social inequalities, worsened by structural adjustment measures from the 1980s on, and combined with a deep re-articulation of state-society relations in a period of serious criticism on modern ideology and faith in future and progress (Innerarity 2008).

\footnotetext{
${ }^{1}$ http://www.consejociudadanobcs.org/ (page accessed in July 14th 2010).
} 


\section{Politicizing fear of crime and insecurity in Caracas}

Fear is existential. Emotions can be tenuously connected with the material reality. But their concreteness is both material and intangible. They are both passion and action at once. Emotions, and fear in this case, are historically, socially, and politically contingent. As well, they rely on subjectivities and individuals. They cut across the emotional and the rational (Latham and McCormack 2004; Pain and Smith 2009). Public opinion, emotions, and feelings are manufactured by social institutions, discourses, or cultural values. Among them, the media could be highlighted, as well as political discourses, or rumors (Chomsky and Herman 2003; Champagne 1990; Morin 1969). As a consequence, in spite of its emotional - and apparently subjective - dimensions, fear of crime is far from being exclusively an individual or a psychological experience. Emotions are intertwined with social status and hierarchies, with recognition and various inequalities. As any other emotion, fear of crime is situated ${ }^{2}$ (Ruggiero et al. 1998; Turner and Stets 2005; Fernandez et al. 2008). But fear has also objective and material consequences on social spaces. A growing number of social and critical geographers are concerned by such issues, and argue for politicizing fear (Evans and Herbert 1989; Smith 1989; Pain 2000; Pain and Smith 2008). By assessing the fears that urban insecurity entails today in Caracas, we are not negating the necessity for public authorities, as far as it is possible, to address any objectively conceived dangerous events. It is not our aim either to minimize the experiences of victimization, either physical or psychological.

Our hypothesis consists in reading pervasive urban fears in Caracas (fear of crime, of aggression, of civil violence) as a double-edged characteristic of a very unequal and disrupted urban society. As a powerful emotion that frames social interactions, we consider fear as a metanarrative that shapes urbanity in an ambivalent way. On the one hand, it is instrumentalized to sustain domination and inequalities that were socially accepted under the myth of "exceptional democracy", as a pathway from discipline to control (Foucault 1975; 2004). On the other hand, it opens a space of opportunities to violently question an appalling social order which is not backed up anymore by state structures, the ideology of progress and modernity, or the economic prosperity of the oil-producing country.

The paper focuses on socially-contingent drivers of fear of crime, and on its implications on a conflictive and mistrustful current urbanity in Caracas. It aims to contribute to understanding the consequences of the Latin-American disruptions of the 1980s and 1990s on urban socio-spatial orders (Portes 1989; Chalmers et al. 1997; Portes and Hoffman 2003) by politicizing the current urbanity driven by fear. As for us, politicizing fear-rooted urbanity means

\footnotetext{
2 As Rachel Pain explains: "Situatedness refers to the ways in which place, as a site where historical and contemporary economic changes interplay with social identities and relations, has an influence upon the fear of crime of people living locally. In other words, as well as relating to the immediate details of environment and neighborhood, fear of crime is historically and socially specific." (Pain 2000, 379).
} 


\section{Politicizing fear of crime and insecurity in Caracas}

three things: contextualizing fear as a social construction; articulating it to power relations, interests and domination; and acknowledging that naming, handling or diffusing fear (the manufacturing of fear) have concrete consequences on social reality. Beyond a technology of control and in a period when the "social question" is back on both academic and political agendas in Latin America (Chalmers et al. 1997) we offer an interpretation of the current urbanity of fear in Caracas as a resource for subversion and emancipation by looking at the current transformations from the angle of hope for change ${ }^{3}$.

In the following pages, urbanity is considered as an historical condition of socio-spatial relationships in the city (Lefebvre 1974), relations characterized by density, diversity, and potentially intense interactions. But in addition to this historical condition (structural framework), we also pay attention to urban practices and interactions (phenomenological experience), and to conceptions of what the "urban" is or ought to be (representational perspective): what we refer to as "urban legends" ("what ought to be said" is the etymological meaning of "legend"). But who "ought to say" what, and what for? How is the enunciation of urban legends established? These are some important questions to consider when accounting for fear of crime in Caracas. By denaturalizing categories and by questioning their boundaries, we address critically the rising fear of crime and insecurity in Caracas, and its socio-spatial implications.

In order to assess fear of crime in Caracas and its performativity in social spaces, we will follow a two-step approach which first consists in setting out the context and the structural features that embody a more practical and immediate understanding of emotions (second step) (Moser 2004; Pain 2000; 2009). Our method is not grounded in a quantitative survey of localized perceptions (as a long-scale project acknowledged in Colombian cities, Moser and Mcllwaine 2000). Our statements rather rely on different types of qualitative data. Since 2002, intermittent, regular fieldwork in Venezuela allowed us to share time with, and in some cases the life and concerns of, Venezuelans, for a period equivalent to almost 3 years. It has helped in understanding some of the main issues currently at stake (Compagnon et al. 2009). In addition, as part of PhD fieldwork on the territorial dimension of urban risks in Caracas, we have been given the opportunity to gather 118 questionnaires in west-side popular households of Caracas. The questions were related to perceptions of risk, memory of disasters, preparedness of the individuals and the hierarchy of threats, giving room for free expression. As for this paper, we mostly use results concerning perceptions of urban insecurity, threats and the representations and practices of urban relationship (local commitment, community sharing, urban order...). A press review was also undertaken, seeking for critical political events (such as the coup d'état in April

\footnotetext{
3 We agree with Pedrazzini and Desrosiers-Lauzon's ambiguous understanding of urban fears in Caracas in this special issue, though in a slightly different vision of hope.
} 


\section{Politicizing fear of crime and insecurity in Caracas}

2002, or the lock out during winter 2003), but also with selected articles from the two main national newspapers, El Nacional and El Universal, openly against Chavez's governments (Rebotier 2008). Finally, what follows also builds on secondary sources by anthropologists, sociologists or media analysts.

As a meaningful ideological and material context, we first present the myth of an "exceptional democracy". Such a mythical narrative serves as a lost reference and supports current urban fears. Then, relying on such an idealized imaginary, we highlight the performativity and the instrumental dimensions of fear of crime by indentifying some structural drivers rooted in inequality, by exploring what is really at stake when feeling frightened, and what are the consequences on Caracas urbanity. Finally, we sketch an alternative viewpoint in terms of fear of crime by adopting the perspective of the marginals ${ }^{4}$.

\section{How to frame order in a democratic and deeply unequal society?}

Fear of insecurity in Caracas conjures negative urbanity as a counter-point to an idealized urban way of life. It evokes plenty of nostalgic references to an "exceptional democracy" which supposedly included the whole Venezuelan people in a peaceful society. Current urban fears in Caracas deeply contrast with a "lost paradise" that has probably never existed.

\subsection{The myth of an exceptional democracy}

In January 1958, the dictatorship of Marcos Pérez Jiménez came to a close. The country turned into a quiet and prosperous democracy whereas many of the other Latin-American countries experienced new dictatorships ruled by military juntas. Venezuela showed the highest national income per capita from mid-1950s until late 1970s (Thorp 1998). In an opulent democracy supported by oil resources, Venezuelans' standards of consumption were famous from Miami to Paris. In the first issue of Le Monde Diplomatique, a Cartier Jeweler's advertising cited world capitals of luxury and beauty: Paris, London, New York, Palm Beach, Cannes, Monte-Carlo... and Caracas (Figure 1).

Figure 1: Front page of the first issue of Le Monde Diplomatique, May 1954.

During these "golden years", large social sectors enjoyed relatively high income. The famous "tá barato, dame dos" (that's cheap, gimme two) turned into an identifying expression. Based on formal

\footnotetext{
4 "Marginals" (marginales) or even "antisocial" people (antisociales) refer to poor people living in barrios.
} 


\section{Politicizing fear of crime and insecurity in Caracas}

liberal democracy, an apparent socio-political harmony and a - selective - prosperity, the - still vivid - myth of an exceptional democracy actually relies on the fantasy of an idealized past of the capital city (Ellner and Tinker Salas 2007). In "La ciudad de los techos rojos" (The city with the red roofs), Bernardo Nuñez depicted in 1947 (2004) a model of urbanity in a set of very "urbane" chronicles ${ }^{5}$. From the chaotic perspectives that characterized Caracas as the "Frankenstein city" at the end of the $20^{\text {th }}$ century (Buitrago Segura 1980; Negrón 1995), the Nuñez' vision seems to be a lost paradise, giving even more room to the myth of exceptionality and to the rejection of the present "ugly, dangerous, awful" capital city. Nevertheless, past myths and current unease seem respectively to hide and strengthen an unequal socio-spatial order actually in crisis.

Indeed, it is obvious how the colonial city organized the social distribution of inhabitants according to the distance to the city center. In the historical novel Los Amos del V alle, Herrera Luque mentions the existence of popular sectors occupying crowded shantytowns in "immoral" areas at the very margins of the city $(1979,13)$. Nowadays, segregated forms are made clear in urban landscape, though at different scales. In 1950, 17\% of the inhabitants of Caracas were living in barrios de ranchos (poor shelters in invaded lands); at the end of the 1970s (on the crest of the highest oil income the country had ever known), the proportion increased to just over $50 \%$. Near the end of the 1990s, it has stabilized below 50\% (De Lisio 2001; Baby-Collin and Zapata 2006). And in political terms, the Venezuelan democracy has been based on an agreement between three (soon-to-become two) parties that would share power for 40 years after 1958. Jointly with the church or powerful unions, the social democrats (Acción Democrática) and the Christian-Democrats (COPEI) were controlling society. As a matter of fact, the quiet democracy appeared to be a strong regime when facing formally excluded political opposition, and particularly its left wing ${ }^{6}$.

\subsection{With the neoliberal turn: the crisis of disciplinary institutions}

As in most of Latin American countries during the last decades of the $20^{\text {th }}$ century, traditional institutions that linked State and society have been undermined by neoliberal transformations (Portes 1989; Chalmers 1997; Portes and Hoffman 2003). During this period, Venezuela and its

\footnotetext{
${ }^{5}$ La ciudad de los techos rojos is the title of urban chronicles about Caracas written by Enrique Bernardo Nuñez. In 1947 the author took the words from the poet Juan Antonio Pérez Bonalde who qualified in this way the city of Caracas at the first sight, in 1878, when he was travelling back home from exile: "Caracas abi está; sus techos rojos, / su blanca torre, sus azules lomas / y sus bandas de tímidas palomas / „Hacen nublar de lágrimas mis ojos!”

${ }^{6}$ The way President Betancourt dealt with student uprisings in the early 1960s (Velásquez et ali 1980, 61-77), and some episodes known as the massacres of Cantaura (1982), Yumare (1986), or El Amparo (1988) that involved public forces in arbitrary assassinations of political opponents (Bolívar 1992, 226-229) are among the darkest hours of a not so peaceful nor exceptional democracy.
} 


\section{Politicizing fear of crime and insecurity in Caracas}

capital city had to face very disruptive transformations and sociopolitical tensions leading to a deep questioning and re-articulation of the former urban order (Gómez Calcaño and Lopez Maya 1990; Lopez Maya 2003; Compagnon et al. 2009). The adjustment package that a weakened Venezuelan State adopted during the late 1980s put an end to the fairy-tale of exceptionality.

During the "lost decade", as the ECLAC called the 1980s, doubt, mistrust, and then rejection spread throughout the city. In 1983, the convertibility between Bolivars and US Dollars was suspended. What most Venezuelans interpreted as transitory actually marked the very beginning of a broader depression. Corruption and political turmoil, leading to the impeachment of the president Carlos Andrés Pérez in 1993, increased mistrust towards traditional political parties. Main unions were not able to respond to such transformations either. Informal work rose to $50 \%$ at the end of the 1990 s. Social cohesion vanished as quickly as "exceptionality" did.

The downfall of this conservative interpretation of what Caracas urbanity was supposed to be during the first forty years of the democratic era crystallized into bloody riots in February 1989: the Caracazo, revealing hidden tensions (Lopez Maya 2003). As a consequence of the adjustment package, prices for basic necessities such as oil (and public transportation) and milk, rose overnight. At daybreak, at the time of taking the bus and going to work, popular neighborhoods rebelled against the cost of transportation. The marginals - among others - burst into the city center and sacked the very ordered and quietly policed Caracas. Anger came from the suburbs to the center, and from the top of the hills covered by barrios de ranchos to the formal areas of the lower city. When covered by popular quarters, hills are called ceros. When wealthier sectors are concerned, the hills are called colinas or lomas. This socially-oriented difference in the naming of similar topographic forms is referred to in a common expression about the Caracazo: "the day when the cerros ran down" (el dia que bajaron los cerros). The expression describing the invasion of the formal city by social margins has turned into a symbol of transgression of an idealized order. Those who came into the center of Caracas were forgotten - negated, repressed - by the myth of exceptionality. Many marginals had no documents (hence were unable to vote), had been working in large numbers in the informal economy, and lived in popular shelters in invaded lands without even appearing on official maps of the city planning services (Baby-Colin 2000). It is worth remembering that by the 1990s, barrios dwellers amounted to almost half the city population.

What was invisible until then, hidden under the fantasy of social cohesion, had, after February 1989, become obvious, and threatened established social statuses. The naïve metanarrative of exceptionality had been "polluted" by the violent outbreak of the outcasts on the public stage (Douglas 2001; Wacquant 2006). The Caracazo, which introduced massive fear in the contemporary narrative of urbanity in Caracas, actually staged violent claims for recognition and 


\section{Politicizing fear of crime and insecurity in Caracas}

the right to exist as integral parts of the city. Marginals who had been making the city (Bolívar 1995) in the shadow of the hegemonic exceptionality had risen as - disturbing - political subjects on the urban stage (Lopez Maya 2002). The emergence of pervasive fears is consistent with the voicing of severe critiques of the conservative and exclusionary vision of Caracas urbanity. Urban norms and references are questioned. An urban meta-narrative is reshaped through the fear of crime, which is not only the result of the crisis. It is also rooted on the same previous social stratification that used to endorse the construction of an exclusionary myth of social cohesion.

Indeed, locating the reasons of the "loss of the city" in the Caracazo events and in the following political troubles (including the arrival of Hugo Chavez at the presidency and his undoubtedly conflictual way of ruling the country) is a misleading interpretation (Briceño León 2007). The "right to the city" was to be claimed for many marginals much before an urbanity of fear emerged in the 1990s and materialized in a crisis of a supposedly exceptional urbanity. The current pervasive fear of crime reveals the tensions and conflicts of a highly unequal society that had been contained until then, thanks to a strong liberal democratic apparatus, no matter the apparent contradictions (Coronil 1997). Fear of crime and insecurity exist. They are widespread in Caracas, and with good reason! As a social and political emotion that turned into a hegemonic narrative of the city, it is worth wondering whose fear it is, and what fear is about. Between a technology of control (Foucault 1975; Caldeira 2000) and a space of hope (Pain and Smith 2008), the next section will explore some of its structural drivers, in order to shed light on the performativity of an urbanity of fear.

\section{Framing order by shaping fears?}

As an e-motion, fear is not only the consequence of an event. It is also productive. It shapes reality in both material and intangible ways. As Pain and Smith state, "the place of fear is as salient as material risk as a driver of political maneuvering and a constraint on personal wellbeing" $(2008,1)$.

\subsection{Urban fears of insecurity are class and race driven}

On the ground, it appears that fear of crime is closer to social and racial divisions than it is to the objective distribution of insecurity (Rebotier 2009). Structural socially-oriented drivers shape emotions, as the two following examples show. The first one is related with urbanism and the other one with structural racism. 


\section{Politicizing fear of crime and insecurity in Caracas}

From the 1920s on, homogeneous residential sectors rooted on the will to live with one's own "group" have been sprawling in and around the city. Such an exclusive community-building named urbanización in Caracas was based on economical, social or cultural criteria. It was inspired by the design of community neighborhoods in the late $19^{\text {th }}$ century United States, where covenants limited neighborhood diversity:

These covenants [...] tell us much not only about the dreams of suburbanites, which have been vividly described by many other historians, but about their nightmares; not only about their hopes but about their fears. About their fear of others, of racial minorities and poor people, once known as "the dangerous classes," and their fear of people like themselves. About their fear of change and their fear of the market, of which they were among the chief beneficiaries" (Fogelson 2005, 23-24).

Referring to Bourgeois Utopia by Robert Fishman (1987), in Bourgeois nightmare Fogelson (2005) relates clearly the desire for homogeneity and exclusivity, and the consequent residential withdrawal. Urban designers such as the Olmsted Brothers, creators of the Palos Verdes development near Los Angeles, designed the very select Country Club of Caracas. Homogeneous residential areas, though with different social status, dominate most of the formal urbanization of Caracas. Such socio-spatial differentiations have characterized the urban landscape for decades.

The boundaries drawn by homogeneity's logics are emotionally strengthened by the current fear of crime (Rebotier 2009). Like in many other cities, the spreading phenomenon of gated communities and secured spaces is obvious in numerous residential areas (Caldeira 2000; Moser 2004; Low 2005). Fear-provoked re-organization is playing the role of a failing State by keeping away those who are supposed to cause insecurity, and consequently inspires fear. The need to put up barriers, guards and fences to control and sometimes prohibit the access to public areas of residential neighborhoods (García Sanchez 2004) is a clear illustration of the deeper socio-spatial fragmentation of an already segregated society. Fences and barriers are materializing what was tacit during the exceptional democracy. Nowadays, the urbanity of fear legitimates the fact that private logics prevail upon collective ones even in the usually shared spaces of the city. The "crisis" of urbanity is consistent with the newfound visibility of frightening inequalities that used to be contained.

Shifting from urbanism to cultural concerns, it appears that racism is also an important driver of differentiations. The anthropologist Patricia Marquez witnessed examples of racism during her fieldwork with young people on the streets of Caracas in the late 1990s.

For the elite, the children and adolescents on the streets (monos, malandros, and chupapegas alike) are disturbing because they seem to represent the ugliness and uncivilized ways of the barbaric 'other'. 


\section{Politicizing fear of crime and insecurity in Caracas}

However, the actual increasing presence of young marginals in city spaces means much more than simply an expansion of 'barbarism' (Marquez 1999: 18).

Actually, what is "more than an expansion of barbarism" in formal urban spaces undermines the idealized meta-narrative of urbanity. Moreover, the otherness of the "barbarians" is obviously transgressing the social and spatial codes of a racialised order. Aiming to reproduce the fantasies of brotherhood, prosperity and social harmony, integration or inclusion are usually mentioned, whereas racial antagonisms echo through daily life:

In Venezuela, we pretend that we live in a racial democracy and think of ourselves as café con leche (literally, coffee with milke) - a racial amalgam of African, European, and Indian elements. We do not experience the same type of virulent, hate-filled discrimination and segregation found in the United-States. However, [...] the social forces shaping the lives of street children speak of the much more subtle forms of racism that are pervasive in Venezuelan society. The colour of the boys' skins affects their ability to get money and food from the general public [...]. (Marquez 1999, 61).

Race is a support for social hierarchy, but also for fear and mistrust. As an example, in 2008, in the car on our way to assess urban sectors on slopes affected by a rain storm, I was told by one of the geologists I accompanied, a thirty-year-old white man: "Watch out with the open window. Someone on a bike could show up and steal or hit you. I'm not racist, but when I see a Negro on a bike, I consider him as a thief, or a delinquent". By associating crime with racist categories, such "talk of crime" is strongly meaningful (Caldeira 2000).

By politicizing fear, we begin to account for societal disruptions since the 1980s as well as long-term deep social and racial inequalities and hostilities. In this way, fear of crime is entangled in power relations, social hierarchies, and cultural statuses. It makes even more sense during a period of social disorder, when old criteria do not work anymore for understanding society. As it is performative, urban fear contributes to make things happen. It works as a force of social ordering following the downfall of the myth of exceptional democracy so that existing social discrepancies keep being identified and transgressions resisted. The first violent transgression, the Caracazo events, broke into a supposedly peaceful and inclusive urbanity and pushed the city into a transition towards another way of urban living where fear might serve as social ordering rule instead of the oil rent and the political arrangement between social democrats and ChristianDemocrats.

\subsection{Stigmatization and distinction: about the instrumentality of fears}

\footnotetext{
${ }^{7}$ He said malandro (see Pedrazzini and Desrosiers-Lauzon's article in this issue).
} 


\section{Politicizing fear of crime and insecurity in Caracas}

In Caracas, fear of crime as a performative emotion had been advocated long before the urban crisis and before the rise of urban insecurity as a core social concern. French geographer Claude Bataillon writing about Caracas in 1965, gives some clues about the way insecurity was then considered:

"In Venezuela, with] the prosperity of oil exploitation that begins in the 1920s, the cities were quickly modernized, thanks to a little army of technocratic engineers, sometimes foreigners, and a highly prosperous middle-class familiar with travels by plane or by car on perfect modern highways. Though in Colombia I could find easy accommodations in old hotels for short staying in the city center, in Venezuela, I have been told not to go to similar hotels, in a city center known to be dangerous. I had to stay in huge modern buildings accessible only by taxi, far away from the universities and other public services" (Bataillon 2008, 66).

In the mid-1960s, in a modern and functionalist city where places were specialized and people separated, the old city center was already considered as dangerous and carefully avoided. Wealthier classes were more familiar with more recent buildings, away from poorer and older sectors of the capital.

Nevertheless, on February 1989, the Caracazo brought critical changes in an already segregated urban society: residential withdrawal and other forms of urban segregation were accentuated; urban insecurity became a key issue in mass media; and grassroots organization in many communities appeared to achieve better local security than the failing State. Daily chronicles and articles dealing with urban insecurity have contributed much in shaping fear of crime (Rotker 2005b). In Santiago Martínez' own words, as president of a grassroots NGO involved in popular neighborhoods, the Caracazo constitutes a breaking point in Venezuelan social history: "The Poor were prone to consider any upper or middle-class neighborhood as a hostile territory; [...and] the middle-class sectors are scared that poor people invade their community" (cited in Ellner and Hellinger 2003, 34-35). Such pervasive representations intensified the shrinking of public spaces, the segregation of territorial practices, and the fragmenting impacts of an urbanity of fear (Rotker 2005a).

"Barrios are perceived by the media and by the elite as the breeding ground for delinquents and as the main source of violence. [...] Barrios exist in the imaginary as a social problem and as a growing cancer in the city" (Marquez 1999, 72-73).

Fear of crime has been continuously characterizing the way to live (in) Caracas from the 1990s on. The election of Hugo Chavez to the presidency in December 1998 and his first populist measures adopted in November 2001 have reactivated and intensified fears of otherness, of a "barbarian" threat, one that is racially and class-oriented (García-Guadilla 2003; Compagnon et 


\section{Politicizing fear of crime and insecurity in Caracas}

al. 2009). In middle-class and upper-middle-class sectors, community contingency plans were drawn up in the early 2000s to face the imminent menace of a popular invasion:

"In some sectors, the plan] recommended that members not be 'too trusting of domestic help, especially those that are day hires. Remember that many of them have been manipulated and some are beginning to see us as the enemy'. The plan was written in response to reports in the Venequelan media that the Circulos Bolivarianos planned to attack middle-class neighbourhoods and homes. It reinforced the stereotype of the chavista as a poor, mislead and violent individual' (Valencia Ramirez 2007, 133).

With a polemical and conflictual rhetoric, President Chavez brought the marginals to the centre of the public stage as legitimate political subjects. In doing so, structural social and spatial antagonisms are reactivated through highly politicized demonstrations in a polarized city, making social inequalities even more visible. Again, in the discourse carried through private media and most of the middle-class sectors, the historical city centre means poor and dangerous sectors of the capital, currently indentified in western Caracas as chavistas sectors. As for Chavez' followers, the wealthier eastern part of the city represents the rearguard of the "capitalists" and political opponents. This high-level politicization of urban spaces has concrete implications for urban experiences. For openly identified opponents, it implies facing a direct threat when the time comes to penetrate western sectors during street demonstrations (Figure 2). Fear spatially materializes and highlights segregated territorial practices and urban representations, between east and west, on the basis of previous social (and today political) divisions.

Figure 2: Itinerary of two political demonstrations in downtown Caracas, before the coup d'état in April 2002.

Source: Author, according to press articles.

Excerpts from one of the main national newspapers give an idea of how a demonstration from opposition-dominated sectors into chavistas sectors can inspire great fear, and how this fear encourages the return of the language of a military campaign:

"The political struggle that was given through an electoral process until then is now settling in the street. Between the two meeting points [the eastern part, opponents; the western part, chavistas], sectors of Los Caobos, Plaza Venezuela and Sabana Grande play the role of a spatial shield, a no man's land" (El Universal, Feburary 9", 2002).

A journalist who was part of the demonstration of December $2^{\text {nd, }} 2001$ is depicting a demonstrator's feelings after leaving the chavista - and hostile - western part of the city: 


\section{Politicizing fear of crime and insecurity in Caracas}

"Now we are safe, we just need to cross Los Chaguaramos, Bello Monte and Las Mercedes to reach El Cafetal" was thinking the lady with the poodle, proud to be alive after her first expedition across the Centre, the first one of many forthcoming others, to claim for Chavez to renounce. The opponents are now decided to take over the street, even by pieces" (El Universal, December 03 ${ }^{\text {rd }}$, 2001).

At the beginning of the $21^{\text {st }}$ century, in a politically polarized city (Ellner and Hellinger 2003), the fears of invasion by under-class and popular masses are reactivated in middle-class sectors. The recent political dynamics merely encourage resurgent fears on the same basis as the ones of the very late 1980s and 1990s. Although 10 years of Chavez presidency have not been revolutionary at all (Compagnon et al. 2009), social and political transformations (such as the recognition of traditionally excluded people as full political subjects) make some sectors feel threatened in a context of persistent inequalities. Fear of crime and insecurity appear to be consistent with a withdrawal from public spaces, and a separation from other groups.

But in spite of powerful and ubiquitous emotions, it is worth noting there are worse things than fear of crime and insecurity in Caracas (rephrasing Wisner 1999). Actually, there are pervasive and persistent inequalities, fears of appalling housing conditions and income issues. Whereas urban fears have become a meta-narrative in Caracas, what about the fears of feared people? In which way may alternative discourses exist? And if they do, what do they advocate?

\section{The marginals' standpoint: whose fear for what kind of (dis)order?}

In this last section, a bottom-up approach to urban fears will be privileged, without detailing routine violence as do Moser and McIlwaine (2000). Here, the objective is to set out a macro perspective based on grounded insights, in order to question the hegemonic conception of fear of crime, and illuminate its social and political significance in the framing of current urbanity in Caracas. Instead of focusing on fear as a technology of ordering (as in part 3), this section seeks to open a window of hope. By considering urban fear from marginals' viewpoints, we evoke it as budding on-going emancipation through which deep inequalities become socially challenging, as seeds of a renewed urban order, and of a new regime of recognition.

\subsection{Urban fears and popular everyday life: what "existential" means}

Even if urban insecurity appears to be a top priority for Venezuelan people, according to the polls aired by the national media almost every week (and Briceño León 2007), it is far from being an exclusive concern. It might appear to be as important as other issues such as housing 


\section{Politicizing fear of crime and insecurity in Caracas}

conditions or work opportunities among the most popular sectors. But, on the ground, it is well known that when you ask for fear, you obtain fear (Kessler 2009). Actually, fear of crime and insecurity is embedded in a larger scope of threatening livelihoods in some barrios de ranchos.

Between June and August 2005 in the popular western sectors of the city, 118 households were surveyed regarding urban risks, daily life routines and representations of risk $^{8}$. The first contacts had been done through networks of local activists. Once introduced in one of the sectors (Niño Jesus), we were given the possibility to expand the survey on a snow-ball logic over similar socio-economic sectors. When people were asked to name "the main threat they were concerned about in their daily life", they first mentioned landslides, then water infiltrations. The hills where the barrios de ranchos are located make landslides a critical issue, as do the lack of watercollecting systems regarding infiltrations. Urban insecurity was ranked in $3^{\text {rd }}$ place, very close to flash floods and earthquakes. When people from the surveyed sectors were asked about "their main concerns regarding the future", housing conditions came first, followed by work opportunities and the search for regular income (Rebotier 2008).

In spite of being objectively the first victims of urban crime, poor people from the said sectors do not mention insecurity as a top priority. This does not mean they disregard security issues. By drawing most of the attention to urban insecurity as an emotional - and thus hard to question - concern, many other crucial concerns cannot be addressed on the public and political stage. On the ground, the questionnaires put forward alternative representations of what is scary and what is not. As a matter of fact, they appear to be rather different from what the dominant, pervasive and fearful discourse suggests. Such popular experiences of the city are neither more nor less valuable than the fear-driven urbanity depicted in most of the media, but they are contingent to the livelihood of marginals. Such concerns and pragmatic priorities deserve better visibility in national, regional and even global contexts that turn security, risks and fears into hegemonic categories in our urban world. In addition to the importance of challenging the mainstream definition of security (by situating it in time, space and society), and to the need to highlight what fear of crime entails in very unequal urban contexts, it is crucial to question the debate on security, and the way to ask questions. Such goals could be achieved by making "hidden mechanisms" visible and obvious, by denaturalizing hegemonic categories, and by addressing what is really at stake with the fear of crime. The hegemonic definition of a pervasive urban insecurity, its reduction to interpersonal insecurity, and the fear of being a victim anytime and anywhere oblivious to any sociological criteria, have hugely contributed to depoliticizing the

\footnotetext{
8 The interviews consisted of a semi-directed survey made of 61 questions that were asked to one of the adults in a the household, in the following sectors: Niño Jesus, Santa Rosa, Sector la Cruz, La Trilla and Briceño Irragory. The survey aimed to explore objective and subjective conditions of risks in popular sectors of Caracas, and with perceptions and representations of risks (Rebotier, 2008).
} 


\section{Politicizing fear of crime and insecurity in Caracas}

issue and to downplaying concerns of social justice (such as social inequalities, cultural recognition and political representation).

\subsection{Beyond the hegemonic fear of insecurity: daring to hope}

Fear, exclusion and stigmatization can be read as technologies of control, by stigmatizing “scapegoats" or out-of-place people (Douglas 2001; Ruggiero et al. 1998). These technologies also consist of incorporated government (Foucault 1975; 2004; Virilio 2007) that allows the reproduction of domination beyond classical authorities and disciplinary institutions. Fear of crime allows urban spaces to be appropriated, qualified or stigmatized. Beyond criminalization (authoritarian forms), fear of crime is an important instrument in the manufacture of socio-spatial differentiation (incorporated control). Such fear relies on the emergence of a vilified disorder that also corresponds to the emergence of newcomers on the political stage. As in the rest of LatinAmerica, the return of the social question has helped to make visible marginalized masses that have been dominated on the basis of social but also cultural or ethnic criteria. As a conservative meta-narrative, the myth of an exceptional democracy and the "magical" - though forcefully unequal - state (Coronil 1997) have been key instruments of social control; so too is today's overwhelming fear of crime, which so easily furthers racial and class-oriented differentiations. Even if it is a generalized concern, fear of crime and insecurity is obviously not addressing the main concerns of the poorest.

Beyond the uncomfortable "living at risk" of interpersonal insecurity that characterizes Caracas and that is made clear to everyone, we also read this reign of fear as an outcome, as an indicator and as a driver of the manufacturing of a renewed urban social order: as the "weapon of the dominated". Understanding fear of crime as agency gives room for such an interpretation. In a way, it denaturalizes what appeared until recently as normal and bearable social order (Harvey 2000). With the disruptive transformations of the late $20^{\text {th }}$ century, the former myth of social cohesion is challenged, and the withdrawal of a traditionally centralized state in Venezuela is the opportunity for different social sectors (unevenly dominated) to claim more political space. The responsibility for security held by the State is no longer assured, and the different kinds of social or political tensions are not constrained either. With the corresponding emergence of urban fears that became ubiquitous in the everyday experiences of the city, a Pandora's Box has been opened in a highly segregated society, turning the hidden mechanisms of domination and socio-spatial segregation into strongly visible and legitimate security measures. But at the same time, fear of crime could be a resource for the marginals to emancipate themselves from earlier forms of 


\section{Politicizing fear of crime and insecurity in Caracas}

domination. E-motions might also bring movement, change, and eventually open a pathway towards a new urbanity that gives room to justice issues in so far as the unequal order is openly questioned and demystified. In other words there is - hopefully - an alternative to unfair urbanity.

\section{Conclusion}

Fear of urban insecurity appears to be the one feeling that most of the people share - though unevenly - throughout the capital city, the last collective element of a fantasy of social cohesion. It is consistent with structural social transformations.

Fear is an ambiguous organizing narrative in an urban society in process of re-ordering after the downfall of the "exceptional democracy". The contingent way it is constructed constitutes an instrument, a technology of control that keeps people separated and that legitimizes socio-spatial stratification. But it is also an indicator of the decline of a kind of domination in a period when the social question is returning as a political issue on many agendas. Over the last three decades, popular masses that were formerly marginalized have been violently claiming recognition and status as full members in the urban order. But when emotions are appealed to, spontaneous support and conviction are no longer strong enough to contain inequalities and tensions: fear becomes the most cohesive social discourse.

Fear is threatening and fascinating at the same time. Between materiality and feelings, its "facticity" stands between hope and despair (Pain and Smith 2008). Current frightening experiences of urban-living in Caracas might be the seed of fundamental, though unexpected, unpredictable and uncomfortable changes. Here is a double-edged symbol between threat and hope that requires politicizing fear as much as hope. Indeed, in addition to drawing upon urban fear of crime and insecurity as an exclusively constraining meta-narrative that shapes an urbanity of partition, we advocate thinking about it as the harbinger of a changing urban narrative that breaks with what usually stands as the "legend" of the chaotic Latin-American city. Here might be a space of opportunities to challenge deep and unquestioned inequalities in a city where social cohesion has been nothing but a myth.

\section{References}

Baby-Collin, Virginie and Emiliano Zapata. 2006. Caracas, entre métropolisation et fragmentation urbaine. Géoconfluences. http://geoconfluences.ens-lsh.fr/doc/typespace/urb1/MetropScient2.htm 


\section{Politicizing fear of crime and insecurity in Caracas}

Baby-Collin, Virginie. 2000. Les marges et la ville, à Caracas et La Paz. L'urbanité dans les Amériques. Eds. Jérôme Monnet and Guénola Capron. Toulouse: Presses Universitaires du Mirail. Bernardo Nuñez, Enrique. 2004. La ciudad de los techos rojos. Caracas: Monte Avila.

Bolívar, Ligia. 1992. La masacre de El Amparo. Sic 545: 226-228.

Bolívar, Teolinda. 1995. Hacedores de ciudad. Caracas: Facultad de Arquitectura y Urbanismo Universidad Central de Venezuela.

Briceño-León, Roberto. 2007. Caracas. Fractured cities. Social exclusión, urban violence \& contested spaces in Latin America. Eds. Kees Koonings \& Dirk Kruijt. London, New York: Zed Books.

Briceño-León, Roberto, Olga Ávila, and Alberto Camardiel. 2009. Inseguridad y violencia en Venezuela. Informe 2008. Caracas: Editorial Alfa.

Buitrago Segura, Luis. 1980. Caracas la horrible. Caracas: El Ateneo de Caracas.

Caldeira, Teresa. 2000. Crime, segregation and citizenship in São Paolo. Berkeley: University of California Press.

Champagne, Patrick. 1990. Faire l'opinion. Le nouvean jeu politique. Paris : Les Editions de Minuit, Paris.

Chomsky, Noam, and Edward S. Herman. 2003. La fabrique de l'opinion publique: la politique économique des médias américains. Paris : Le Serpent à Plumes.

Compagnon, Olivier, Julien Rebotier, and Sandrine Revet. 2009. Le Venezuela au-delà du mythe. Chavez, la démocratie, le changement social. Paris: Editions de L'Atelier.

Coronil, Fernando. 1997. The magical state. Nature, money and modernity in Venezuela. Chicago and London: The University of Chicago Press.

Davis, Mike. 1998. Ecology of Fear. Los Angeles and the Imagination of Disaster. New York: Metropolitan Books.

Lisio, Antonio. 2001. La evolución urbana de Caracas, indicadores e interpretaciones sobre el desarrollo de la interrelación ciudad-naturaleza. Revista Venezolana de Geografia 42 (2): 203-226.

Ellner, Steve, and Miguel Tinker Salas. 2007. The Venezuelan Exceptionalism Thesis : Separating Myth from Reality. Venezuela, Hugo Chavez, and the decline of an "exceptional democracy ». Eds. Ellner, Steve, and Miguel Tinker Salas. Rowman and Littlefield.

Ellner, Steve, and Daniel Hellinger. 2003. Venezuelan politics in the Chávez era: class, polarization, and conflict, Boulder: Rienner.

Evans, David, and David Herbert. 1989. The geography of crime. London and New York: Routledge.

Fernandez, Fabrice, Samuel Leze, and Hélène Marche. 2008. Le langage social des émotions. Etudes sur les rapports au corps et à la santé. Paris : Economica, Anthropos. 


\section{Politicizing fear of crime and insecurity in Caracas}

Foucault, Michel. 2004. Sécurité, territoire, population. Cours au Collège de France. 1977-1978. Paris: Editions de l'EHESS.

Foucault, Michel. 1975. Surveiller et punir : naissance de la prison. Paris: Gallimard.

García-Guadilla, María Pilar. 2003. Civil society: institutionalization, fragmentation, autonomy. Venezuelan politics in the Chávez, era: class, polarization, and conflict. Eds. Steve Ellner, and Daniel Hellinger. Boulder: Rienner.

García Sanchez, Pedro José. 2004. La forme privative de l'urbanité : emprise sécuritaire et homogénéisation socio-spatiale à Caracas. Espace Géographique 2004 (2): 1-17.

Glassner, Barry. 1999. The culture of fear: why Americans are afraid of the wrong things. Basic Books.

Gómez Calcaño, Luis, and María López Maya. 1990. El tejido de Penélope. La reforma del Estado en Venezuela (1984-1988). Caracas: Cendes-APUCV-IPP.

Harvey, David. 2000. Spaces of hope. Berkeley: University of California Press

Herrera Luque, Francisco. 1979. Los amos del Valle. España: Pomaire.

Innerarity, Daniel. 2008. Le futur et ses ennemis. De la confiscation de l'avenir à l'espérance politique. Paris: Flammarion.

Kessler, Gabriel. 2009. El sentimiento de Inseguridad. Sociología del temor al delito. Buenos Aires, Siglo XXI.

Kruijt, Dirk, and Koonings, Kee. 1999. Societies of fear: the legacy of civil war, violence and terror in Latin America. London and New York: Zed Books.

Latham, Alan, and Derek McCormack. 2004. Moving cities: rethinking the materialities of human geographies. Progress in Human Geography 28 (6): 701-724.

Lefebvre, Henri. 1974. La production de l'espace. Paris : Anthropos.

López Maya, María. 2003. The Venezuelan Caracazo of 1989: popular protest and institutional weakness. Journal of Latin American Studies 35: 117-137.

López Maya, María. 2002. Venezuela after the Caracazo: forms of protest in a deinstitutionalized context. Bulletin of Latin American Research 21 (2): 199 - 218.

Low, Setha. 2005. Towards a Theory of Urban Fragmentation: A Cross-Cultural Analysis of Fear, Privatization, and the State. Cybergeo. http://www.cybergeo.eu/index3207.html

Morin, Edgar. 1969. La rumeur d'Orléans. Paris: Seuil.

Moser, Caroline. 2004. Urban violence and insecurity: an introductory roadmap. Environment and urbanization 16 (2): 3-16.

Moser, Caroline, and McIlwaine, Cathy. 2000. Urban poor perception of violence and exclusion in Colombia. Washington: The World Bank. 


\section{Politicizing fear of crime and insecurity in Caracas}

Negrón, Marco. 1995. El crecimiento metropolitano vergonzante: la expansión en la segunda mitad del siglo XX. Caracas, memorias para el futuro. Eds. Giuseppe Imbesi, and Elisenda Vila. Roma: Gangemi Editore.

Pain, Rachel. 2009. Globalized fear? Towards an emotional geopolitics. Progress in Human Geography 33 (4): 466-486.

Pain, Rachel. 2000. Place, social relations and the fear of crime: a review. Progress in Human Geograpby 24 (3): 365-387.

Pain, Rachel and Susan J. Smith. 2008. Fear: critical geopolitics and everyday life (Re-materializing cultural geography). Ashgate.

Portes, Alejandro. 1989. Latin American Urbanization during the Years of the Crisis. Latin American Research Review 24 (3): 7-44.

Portes, Alejandro, and Kelly Hoffman. 2003. Latin American Class Structures: Their Composition and Change during the Neoliberal Era. Latin American Research Review 38 (1): 41-82.

Rebotier, Julien. 2009. Seguridad urbana y urbanismo del miedo: comportamientos defensivos y distanciación social en Caracas. Rethinking inequalities. Rio de Janeiro: LASA Congress. http://hal.archives-ouvertes.fr/docs/00/37/33/37/PDF/Rebotier_LASA.pdf

Rebotier, Julien. 2008. Les territorialités de risque urbain à Caracas. Les implications d'un construit sociospatial dans une métropole latino-américaine. Paris: Université Paris 3 - Sorbonne Nouvelle.

Rotker, Susan. 2005a. Bravo pueblo. Poder, utopía y violencia. Caracas: Fondo editorial La Nave.

Rotker, Susan. 2005b. La crónica. Género de fin de siglo. Bravo pueblo. Poder, utopía y violencia. Ed. Susan Rotker. Caracas: Fondo editorial La Nave.

Ruggiero, Vincenzo, Nigel South, and Ian Taylor. 1998. The new European criminology. Crime and social order in Europe. London: Routledge.

Smith, Susan. 1989. Social relations, neighborhood structure, and the fear of crime in Britain. The geography of crime. Eds. David Evans, and David Herbert. London and New York: Routledge.

Thorp, Rosemary. 1998. Progress, poverty and exclusion: an economic history in Latin America in the 20 th Century. Inter-American Development Bank.

Turner, Jonathan, and Jan Stets. 2005. Sociology of emotions. Cambridge: Cambridge university press. Valencia Ramírez, Cristóbal. 2007. Venezuela's Bolivarian Revolution: who are the chavistas? Veneruela, Hugo Chavez and the decline of an «exceptional democracy». Eds. Steve Ellner, and Miguel Tinker Salas. Rowman and Littlefield.

Velásquez, J. Ramón, Sucre J. F. Figarella, and Blas Bruni Celli. 1980. Betancourt en la historia de $V$ enezuela del siglo XX. Caracas: Avila Arte.

Virilio, Paul. 2007. City of panic. Oxford: Berg. 
Politicizing fear of crime and insecurity in Caracas

Wacquant, Loïc. 2006. Parias urbains, ghettos, banlienes, Etat. Paris: La Découverte.

Wisner, Ben. 1999. There are worse things than earthquakes: hazard, vulnerability and mitigation

capacity in greater Los Angeles. Crucibles of hazard: Mega-cities and disasters in transition. Ed. James K.

Mitchell. Tokyo, New York, Paris: United Nations University Press. 